\title{
Spectroscopic Characteristics of Dissolved Organic Matter in Afforestation Forest Soil of Miyun District, Beijing
}

\author{
Shi-Jie Gao, ${ }^{1,2}$ Chen Zhao, ${ }^{2}$ Zong-Hai Shi, ${ }^{3}$ Jun Zhong, ${ }^{2}$ Jian-Guo Liu, ${ }^{2}$ and Jun-Qing Li ${ }^{1}$ \\ ${ }^{1}$ College of Forestry, Beijing Forestry University, Beijing 100083, China \\ ${ }^{2}$ Key Laboratory of Urban Stormwater System, Beijing University of Civil Engineering and Architecture, Beijing 100044, China \\ ${ }^{3}$ Beijing Industrial Technician College, Beijing 100023, China
}

Correspondence should be addressed to Shi-Jie Gao; gaoshijie2006@163.com

Received 6 April 2016; Accepted 30 May 2016

Academic Editor: Miguel de la Guardia

Copyright (C) 2016 Shi-Jie Gao et al. This is an open access article distributed under the Creative Commons Attribution License, which permits unrestricted use, distribution, and reproduction in any medium, provided the original work is properly cited.

\begin{abstract}
In this study, soil samples collected from different plain afforestation time (1 year, 4 years, 10 years, 15 years, and 20 years) in Miyun were characterized, including total organic carbon (TOC), total nitrogen (TN), total phosphorus (TP), available $\mathrm{K}\left(\mathrm{K}^{+}\right)$, microbial biomass carbon (MBC), and dissolved organic carbon (DOC). The DOM in the soil samples with different afforestation time was further characterized via DOC, UV-Visible spectroscopy, excitation-emission matrix (EEM) fluorescence spectroscopy, and ${ }^{1} \mathrm{H}$ NMR spectroscopy. The results suggested that the texture of soil sample was sandy. The extracted DOM from soil consisted mainly of aliphatic chains and only a minor aromatic component. It can be included that afforestation can improve the soil quality to some extent, which can be partly reflected from the indexes like TOC, TN, TP, $\mathrm{K}^{+}, \mathrm{MBC}$, and DOC. And the characterization of DOM implied that UV humic-like substances were the major fluorophores components in the DOM of the soil samples, which consisted of aliphatic chains and aromatic components with carbonyl, carboxyl, and hydroxyl groups.
\end{abstract}

\section{Introduction}

Urban forestry is often regarded as a key ecological asset of a city, which can significantly improve the ecoenvironment by lowering urban temperature by reducing heat island effect, improving air quality by absorbing pollutants, mitigating urban waterlogging by quick infiltration of stormwater runoff, and enhancing biodiversity by provision of habitat for living things. Each year, many efforts are put into urban afforestation in China, which led to the increase of the total forest area and the amount of forest reserves, further to make the cities more attractive and livable [1]. In case of Beijing, the capital of China, a large-scale plain reforestation project was launched, in which $133,000 \mathrm{hm}^{2}$ afforestation forest was planned to increase each year from 2012 to 2015 [2].

Up to now, numerous studies have been carried out to investigate the characters of forest soil [3-5] and the dissolving organic matter in farmland soil [6], but few attentions were put to study the soil status of urban afforestation area. In order to assess the soil quality of urban afforestation, the dissolved organic matter (DOM), as the part of organic matter, was deemed to play a significant role in soil biological activity $[7,8]$. And DOM can be regarded as a measure of soil quality and an integral part in a forest ecosystem, as its presence can increase the forest production by reducing erosion, increasing the elasticity, porosity, and water retention [9]. It is the most active and labile fraction with different molecular sizes, structures, and functional properties $[8,10]$ and exhibits heterogeneous nature as it is composed of the diverse and complicated compounds with different functional groups like aliphatic/phenolic hydroxy, amino, and carbohydrates [11, 12].

Generally, DOM plays an important role in the growth of plants due to its molecular structure. And it helps to break up clay and compacted soils, assists in transferring nutrients from the soil to the plant, and enhances water retention. Hence, to understand the dynamics of plant growth, it is necessary to know how DOM is distributed throughout the soil. In this paper, Miyun District, which was a typical afforestation area in Beijing, was chosen as sampling area. And the 


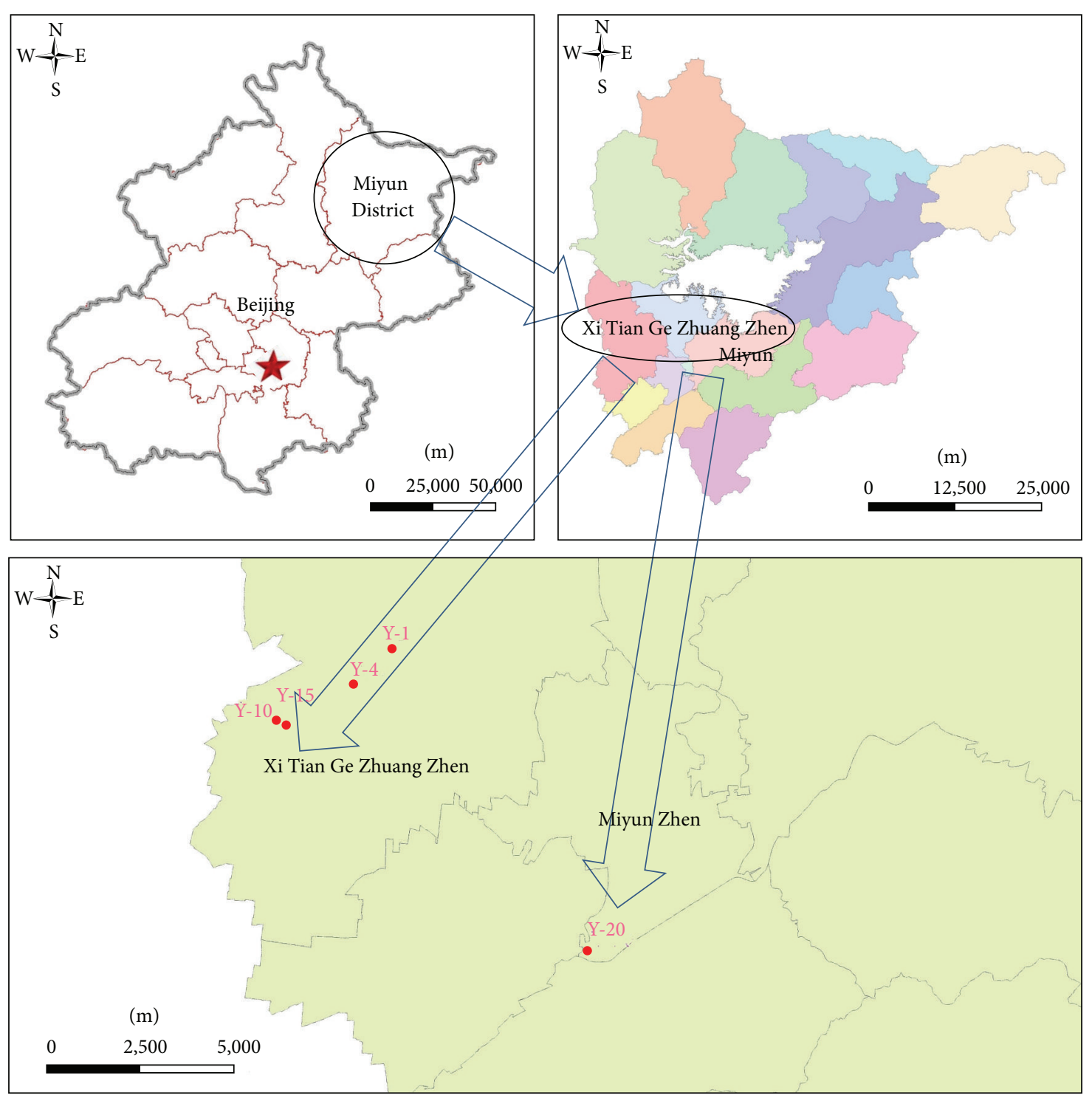

FIGURE 1: Schematic map of the selected area and the sampling sites.

total organic carbon (TOC), total nitrogen (TN), total phosphorus (TP), available potassium $\left(\mathrm{K}^{+}\right)$, microbial biomass carbon $(\mathrm{MBC})$, and dissolved organic carbon (DOC) were determined. The DOM in the soil samples with different afforestation time was extracted and further characterized via dissolved organic carbon (DOC), UV-Visible spectroscopy, EEM fluorescence spectroscopy, and ${ }^{1} \mathrm{H}$ NMR spectroscopy. Some valuable information on the soil quality of afforestation area can be provided, which will guide the future afforestation and corresponding management plan in Beijing.

\section{Materials and Experimental}

2.1. Sampling Sites Description. As a typical afforestation area, Xi Tian Ge Zhuang town of Miyun District was selected as sampling region, as illustrated in Figure 1. The mean annual rainfall and average temperature of this area is $661.3 \mathrm{~mm}$ and $10.8^{\circ} \mathrm{C}$, respectively. Five sampling regions with different plain afforestation time (1 year, 4 years, 10 years, 15 years, and 20 years) were selected in this study, and the samples were collected on June 27th, 2015 (Table 1). At each sampling area, 5 samples were collected with columns of $20 \times 5 \mathrm{~cm}$ (long $\times$ diameter) via Soil Core Samplers (AMS samplers, American Falls, Idaho) $[9,13]$.

2.2. Pretreatment of the Soil Samples. In laboratory, after the visible roots, plant fragments, grass, and tones were removed, the soil samples were dried in the open air, passed through a $2 \mathrm{~mm}$ sieve, and stored at room temperature in airtight glassware containers [5].

2.3. The Determination of Some Soil Parameters. Soil bulk density was measured according to M.A. Rab using bulk density soil sampling kit (AMS samplers, American Falls, Idaho) [14]. The distribution of soil particle was analyzed with Mastersizer 3000 (Malvern Instrument Ltd., UK) to determine 
TABLE 1: Locations and afforestation information of the samples.

\begin{tabular}{lccc}
\hline Abbreviation & Tree species & Growing period & Coordinates \\
\hline Y-1 & Pagoda tree & $1 \mathrm{yr}$ & $\mathrm{N}^{\circ} 20^{\circ} 59.6^{\prime \prime}, \mathrm{E} 116^{\circ} 45^{\prime} 43.7^{\prime \prime}$ \\
Y-4 & Pagoda tree & $4 \mathrm{yrs}$ & $\mathrm{N}^{\circ} 20^{\circ} 24^{\prime} 30.8^{\prime \prime}, \mathrm{E} 116^{\circ} 45^{\prime} 00.0^{\prime \prime}$ \\
Y-10 & Populus tomentosa & $10 \mathrm{yrs}$ & $\mathrm{N}^{\circ} 20^{\circ} 23^{\prime} 58.4^{\prime \prime}, \mathrm{E} 116^{\circ} 43^{\prime} 41.6^{\prime \prime}$ \\
Y-15 & Populus tomentosa & $15 \mathrm{yrs}$ & $\mathrm{N} 40^{\circ} 24^{\prime} 00.7^{\prime \prime}, \mathrm{E} 116^{\circ} 43^{\prime} 37.1^{\prime \prime}$ \\
Y-20 & Shrub and locust & $20 \mathrm{yrs}$ & $\mathrm{N} 40^{\circ} 20^{\prime} 52.2^{\prime \prime}, \mathrm{E} 116^{\circ} 49^{\prime} 22.0^{\prime \prime}$ \\
\hline
\end{tabular}

the content of clay, silt, and sand in the soil samples [15]. The $\mathrm{pH}$ values of the soil were measured in a suspension (water/dry soil, 2.5:1) using a PB-10 pH meter (Sartorius, Germany) [16]. Microbial biomass carbon (MBC) analysis was determined by the chloroform fumigation-extraction method [17]. Total organic carbon (TOC) was calculated by subtracting inorganic carbon (calculated from $\mathrm{CaCO}_{3}$ content) from total carbon by a Jena multi N/C 3100 analyzer [18]. The total N, P, and available P of the soil sample were measured using a AA3 continuous-flow analyzer (Seal Analytical Corporation, Germany). The available K was measured by flame atomic absorption spectrometric method via Perkin Elmer 9100 Atomic Absorption Spectrometry.

2.4. DOM Extraction and Analytical Methods. $10.0 \mathrm{~g}$ soil sample was mixed with $50.0 \mathrm{~mL}$ distilled water in $100.0 \mathrm{~mL}$ centrifuge tube, which was shaken at $200 \mathrm{r} / \mathrm{min}$ in a reciprocal shaker for $16 \mathrm{~h}$ under room temperature $\left(25^{\circ} \mathrm{C}\right)$, and then centrifuged at $12000 \mathrm{r} / \mathrm{min}$ for $20 \mathrm{~min}$. The supernatant was moved out of centrifuge tube with a hydrophilic PVDF Millipore membrane filter $(0.45 \mu \mathrm{m})$ to carry out the following characterizations like dissolved organic carbon (DOC), UV-Visible spectroscopy, excitation-emission matrix (EEM) fluorescence spectroscopy, and even ${ }^{1} \mathrm{H}$ NMR spectroscopy.

2.5. UV-Visible Spectroscopy. UV-Visible spectra of the DOM in filtered supernatant were recorded from 200 to $600 \mathrm{~nm}$ on a PerkinElmer Lambda 650 S spectrophotometer using a $1.0 \mathrm{~cm}$ quartz cell [19]. The absorbance at $300 \mathrm{~nm}$ was adjusted to 0.02 to avoid inner filter effects [20]. Ultrapure water (Milli-Q, $18 \mathrm{M} \Omega \cdot \mathrm{cm}$ ) was selected as the blank.

2.6. Excitation-Emission Matrix (EEM) Fluorescence Spectroscopy. The excitation and emission spectra of the DOM in filtered supernatant were measured on a Hitachi F-7000 fluorescence spectrophotometer using a $150 \mathrm{~W}$ xenon arc lamp as the light source. Both excitation and emission slits are $10 \mathrm{~nm}$ with a scan range from $200 \mathrm{~nm}$ to $550 \mathrm{~nm}$. The scan rate was $1200 \mathrm{~nm} / \mathrm{min}$, and the photomultiplier tube voltage was $700 \mathrm{~V}$. The standard quinine sulfate units (QSU) were introduced to determine the samples' relative fluorescent intensities; that is, 42.21 intensity unit is equivalent to one QSU $\left(1 \mathrm{QSU}=1 \mu \mathrm{g} \mathrm{L}^{-1}=1 \mathrm{ppb}\right.$ quinine sulfate in $0.05 \mathrm{~mol} \mathrm{~L}^{-1}$ $\left.\mathrm{H}_{2} \mathrm{SO}_{4}\right)[21,22]$. The Rayleigh scatter effects were eliminated from the data set by adding zero to the EEMs in the two triangle regions $(\mathrm{Em} \leq \mathrm{Ex}+20 \mathrm{~nm}$ and $\mathrm{Em} \geq 2 \mathrm{Ex}-$ $10 \mathrm{~nm}$ ) [23], along with Raman scatter that was avoided by subtracting the background value of the ultrapure water as blank $[23,24]$ to highlight the useful fluorescent information.
2.7. ${ }^{1} H$ NMR Spectroscopy. Agilent VacElut SPS 24 solid phase extraction (SPE) equipment with Bond Elut C-18 as sorbent was selected to isolate the DOM from the samples, in which $10.0 \mathrm{~mL}$ leaching liquor extracted from soil sample was pumped through the SPE column with the speed of $1.0 \mathrm{~mL} / \mathrm{min}$. Two $5.0 \mathrm{~mL}$ ultrapure water solvents were used to pass through the SPE column to wash off the residual salts. The DOM held in the C-18 packing of SPE column was eluted off with $6 \mathrm{~mL}$ solution matrix of water and methanol with volume ratio of 1: 9 . The reduced pressure was stained for $30 \mathrm{~min}$ to remove the residual solvent [21]. Finally, the extracted DOM was dried under $\mathrm{N}_{2}$ gas with Termovap Sample Concentrator (YGC-1217, Bao Jing Company) [22]. In order to conduct ${ }^{1} \mathrm{H}$ NMR spectroscopy analysis, the obtained solid DOM extracts were dissolved in $\mathrm{D}_{2} \mathrm{O}$ (Jin Ouxiang Company) to avoid water peaks. Measurements of ${ }^{1} \mathrm{H}$ NMR spectra of the DOM were performed on a Bruker 400 M NMR spectrometer. The pulse conditions of ${ }^{1} \mathrm{H}$ NMR were listed as the following: operating frequency $=499.898 \mathrm{MHz}$, acquisition time $=2.045 \mathrm{~s}$, recycle delay $=1.0 \mathrm{~s}$, and line broadening $=$ $1.0 \mathrm{~Hz}$. The standard s2pul pulse sequence and baseline correction was applied. The functional groups in the ${ }^{1} \mathrm{H}$ NMR spectra were identified on their corresponding chemical shifts $\left(\delta_{\mathrm{H}}\right)$ relative to that of the water $(4.7 \mathrm{ppm})$ [25].

\section{Results and Discussion}

3.1. Soil Texture and Soil Quality Indicators. The basic physical and chemical properties of the soil samples are assessed. As listed in Table 2, it can be seen that all of the soil samples selected in this study are sandy texture, with a silt/sand ratio ranging from $73.89 \%$ to $92.64 \%$, and the bulk densities were in the range of $1.45-1.57 \mathrm{~g} \cdot \mathrm{cm}^{-3}$, which matched well the previously reported values [26]. As shown in Table 3, the basic indexes of soil fertility, total organic carbon (TOC), total nitrogen (TN), total phosphorus (TP), and available potassium (K) are ranging from 2.64 to $4.52 \mathrm{~g} \cdot \mathrm{kg}^{-1}, 0.03$ to $0.05 \mathrm{~g} \cdot \mathrm{kg}^{-1}, 0.05$ to $0.48 \mathrm{~g} \cdot \mathrm{kg}^{-1}$, and 0.21 to $0.61 \mathrm{~g} \cdot \mathrm{kg}^{-1}$, respectively. The TOC increases with the increasing of the afforestation time when the afforestation time is less than ten year and then remains nearly constant when the time is up to ten year. The microbial biomass carbon analysis (MBC) and water extracted dissolved organic carbon (DOC) are in the range of 16.28 to $92.70 \mathrm{mg} \cdot \mathrm{kg}^{-1}$ and 56.08 to $81.10 \mathrm{mg} \cdot \mathrm{kg}^{-1}$, respectively. The highest MBC $\left(92.70 \mathrm{mg} \cdot \mathrm{kg}^{-1}\right)$ is observed at sample Y-20. All of the basic physical and chemical properties of the samples are shown that the afforestation can improve biomass in soil. 
TABLE 2: Basic physical properties of the soil samples.

\begin{tabular}{lcccc}
\hline Sample point & Clay (\%) & Silt (\%) & Sand (\%) & $\begin{array}{c}\text { Bulk density } \\
\left(\mathrm{g} \cdot \mathrm{cm}^{-3}\right)\end{array}$ \\
\hline Y-1 & 0.21 & 7.15 & 91.23 & 1.57 \\
Y-4 & 0.94 & 20.75 & 78.30 & 1.49 \\
Y-10 & 0.82 & 23.24 & 75.94 & 1.45 \\
Y-15 & 0.25 & 10.04 & 89.71 & 1.51 \\
Y-20 & 1.14 & 24.97 & 71.89 & 1.51 \\
\hline
\end{tabular}

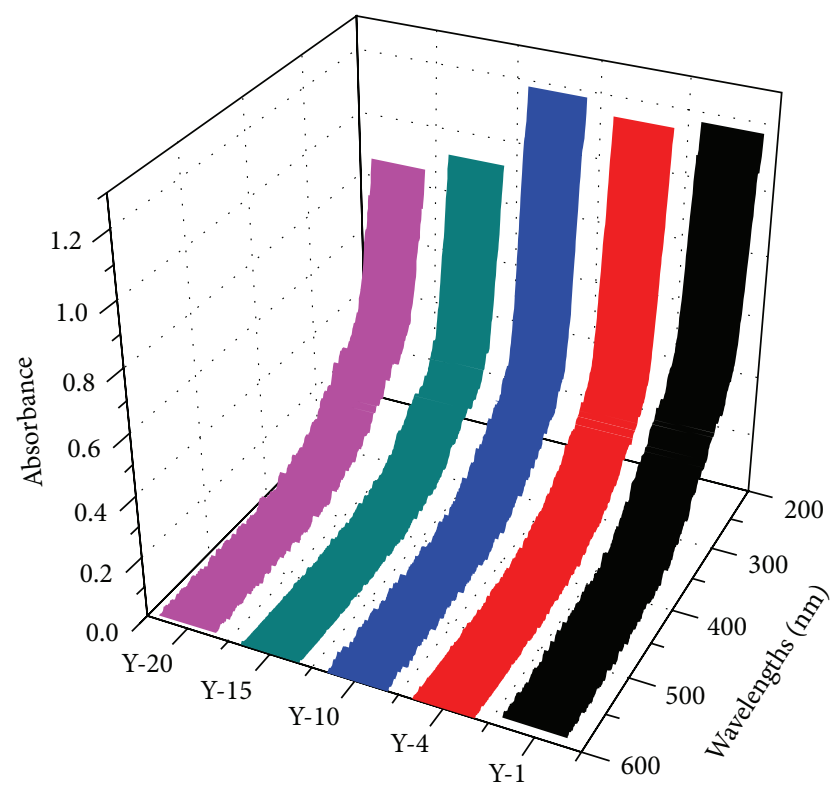

Figure 2: UV-Visible spectra of the soil samples.

\subsection{Spectroscopic Characteristics of DOM in Soil Samples}

3.2.1. UV-Visible Spectroscopy. As an efficient tool, the UVVisible spectroscopy is employed to evaluate the composition and structure of DOM $[27,28]$. As illustrated in Figure 2, all the UV-Visible spectrum absorbance of the five samples decreased with the wavelength, which can be found in other studies $[5,24,29,30]$. Some small shoulder peaks can be found in the region of $250-300 \mathrm{~nm}$, which might be contributed by phenolic, aromatic carboxylic, and polycyclic aromatic compounds ( $\pi \rightarrow \pi^{*}$ transition) [31].

The spectral slope coefficients $(S)$ calculated from the UVVisible spectra data exhibited the light absorption efficiency of DOM as a function of the wavelength, which negatively relates to molecular weight of DOM [32, 33]. Jamieson et al. calculated $S$ values within the spectra region of $275-295 \mathrm{~nm}$ to characterize the biochar-derived DOM isolated from soil [32], and Stedmon et al. calculated $S$ values in the region from 300 to $650 \mathrm{~nm}$ to investigate the molecular weight of DOM in Danish coastal water bodies [34]. To avoid the use of spectral data near the detection limit of the instruments, the ratio of the slope of the shorter wavelength region $(275-295 \mathrm{~nm}$, $\left.S_{275-295}\right)$ to that of the longer wavelength region (350-400 nm, $\left.S_{350-400}\right)$ was calculated, and this dimensionless parameter can be called $S_{R}[33]$.
The $S$ and $S_{R}$ values were calculated as follows:

$$
\begin{aligned}
a(\lambda) & =a\left(\lambda_{0}\right) e^{S\left(\lambda_{0}-\lambda\right)}+K, \\
a(\lambda) & =\frac{2.303 A(\lambda)}{l}, \\
S_{R} & =\frac{S_{275-295}}{S_{350-400}},
\end{aligned}
$$

in which, $a(\lambda)$ and $a\left(\lambda_{0}\right)$ represent absorption coefficients and absorption coefficients at reference wavelength, respectively. $\lambda$ and $\lambda_{0}$ are the reference wavelength $(300 \mathrm{~nm}$ was selected in this study) and the selected wavelength (ranging from $240 \mathrm{~nm}$ to $400 \mathrm{~nm}$ ), respectively. $A(\lambda)$ represents the absorbance at wavelength $\lambda(\mathrm{nm}), l(\mathrm{~m})$ is the optical path length $(0.01 \mathrm{~m}$ in this study), and $K$ is a background $d$ parameter to improve the goodness of fitting.

The median of $S_{R}$ values determined for the DOM samples of the five sits (Y-1, Y-4, Y-10, Y-15, and Y-20) was $0.64,1.07,0.92,0.95$, and 0.77 , respectively, suggesting that the molecular weight of DOM in the soil samples is Y-1 > Y-20 > $\mathrm{Y}-10>\mathrm{Y}-15>\mathrm{Y}-4$.

In order to explore the aromaticity of the DOM samples, SUVA $_{254}$ was introduced as follows:

$$
\mathrm{SUVA}_{254}=\frac{a_{254}}{\mathrm{DOC}}
$$

where $a_{254}\left(\mathrm{~m}^{-1}\right)$ is the absorbance coefficient measured at $254 \mathrm{~nm}$. The median values of $\mathrm{SUVA}_{254}$ were 5.39, 5.90, 4.83, 5.33 , and $4.39 \mathrm{~L} \mathrm{mg} \mathrm{C}^{-1} \mathrm{~m}^{-1}$ for Y-1, Y-4, Y-10, Y-15, and Y20 , respectively. The previously reported $\mathrm{SUVA}_{254}$ values of wetland soil [35] and the agricultural soil [27] were 3.514.41 and $0.32-4.65$, respectively, suggesting that the DOM in our study contained a greater amount of aromatic structures. And previous studies proposed that different landscapes were likely to produce different types of DOM [36, 37]; therefore, the $\mathrm{SUVA}_{254}$ values in this study could roughly imply that afforestation in suburban area can produce the aromatic substances. The highest values of $\mathrm{SUVA}_{254}$ were observed at Y-4, while the lowest values were observed at Y-20.

3.2.2. Excitation-Emission Matrix (EEM) Fluorescence Spectroscopy. The excitation-emission matrix (EEM) fluorescence technique is powerful to provide sufficient information on DOM's molecular size, chemical composition, and aromaticity or aliphatic properties [5, 27]. EEM can identify humic-like (designated as $\mathrm{A}, \mathrm{C}$, and $\mathrm{M}$ ) and protein-like fluorescence peaks ( $\mathrm{B}$ and $\mathrm{T}$ ), as listed in Table 4. EEM fluorescence spectra of the study areas samples were depicted in Figures 3(a)-3(e), suggesting that the UV humic-like substances were the primary fluorophores components in the DOM extracted from afforestation land samples [38]. The first identified peak (peak A) was located at Ex/Em of $257 \mathrm{~nm} / 448 \mathrm{~nm}, 256 \mathrm{~nm} / 440 \mathrm{~nm}, 262 \mathrm{~nm} / 443 \mathrm{~nm}, 260 \mathrm{~nm} /$ $425 \mathrm{~nm}$, and $260 \mathrm{~nm} / 435 \mathrm{~nm}$ for the Y-1, Y-4, Y-10, Y-15, and Y-20 samples, respectively, suggesting the existence of UV humic-like substances. The second typical peak (peak T) was observed at $\mathrm{Ex} / \mathrm{Em}$ of $271 \mathrm{~nm} / 347 \mathrm{~nm}, 280 \mathrm{~nm} / 325 \mathrm{~nm}$, 
TABLE 3: Basic chemical properties of the soil samples.

\begin{tabular}{|c|c|c|c|c|c|c|c|}
\hline Sample point & $\mathrm{pH}$ & $\mathrm{TN}\left(\mathrm{g} \cdot \mathrm{kg}^{-1}\right)$ & $\mathrm{TP}\left(\mathrm{g} \cdot \mathrm{kg}^{-1}\right)$ & Available K $\left(\mathrm{mg} \cdot \mathrm{kg}^{-1}\right)$ & TOC $\left(\mathrm{g} \cdot \mathrm{kg}^{-1}\right)$ & $\mathrm{MBC}\left(\mathrm{mg} \cdot \mathrm{kg}^{-1}\right)$ & DOC $\left(\mathrm{mg} \cdot \mathrm{kg}^{-1}\right)$ \\
\hline Y-1 & 6.34 & 0.03 & 0.09 & 0.51 & 2.64 & 16.28 & 81.10 \\
\hline $\mathrm{Y}-4$ & 6.33 & 0.05 & 0.19 & 0.30 & 2.77 & 42.09 & 68.45 \\
\hline Y-10 & 6.57 & 0.02 & 0.21 & 0.25 & 4.45 & 19.64 & 61.25 \\
\hline Y-15 & 6.65 & 0.02 & 0.48 & 0.21 & 4.52 & 59.45 & 56.08 \\
\hline Y-20 & 7.05 & 0.03 & 0.05 & 0.61 & 4.45 & 92.70 & 69.43 \\
\hline
\end{tabular}

TABLE 4: Peaks, description, and excitation/emission maxima of fluorescent DOM.

\begin{tabular}{lccc}
\hline Peaks & Description & Excitation max $(\mathrm{nm})$ & Emission max $(\mathrm{nm})$ \\
\hline A & UV humic-like, less aromatic & $<260$ & $380-460$ \\
C & Visible humic-like, more aromatic & $320-360$ & $420-460$ \\
M & Marine-humic-like & $290-310$ & $370-410$ \\
B & Tyrosine-like substances & 260 & 280 \\
T & Protein-like tryptophan & $250-300$ & $305-355$ \\
\hline
\end{tabular}

$275 \mathrm{~nm} / 338 \mathrm{~nm}, 279 \mathrm{~nm} / 333 \mathrm{~nm}$, and $271 \mathrm{~nm} / 339 \mathrm{~nm}$ for the five samples stated above, respectively, implying the presence of tryptophan protein-like components [38]. Generally, DOM in soil is affected by some factors like local geology, land use, and microbial and human activities [38]. And it can be believed that the presence of tryptophan protein-like substances could further confirm the larger molecular weight DOM presented in the soil $[39,40]$.

Moreover, the fluorescence intensities of the five sites (Y-1, Y-4, Y-10, Y-15, and Y-20) for peak A were 24, 60, 78, 63, and 81 QSU, respectively, while the peak T fluorescence intensities of the five sites were 8.34, 91, 106, 76, and 124 QSU, respectively.

Three typical fluorescence indices like the fluorescence index (FI), the humification index (HIX), and the biological index (BIX) were selected to investigate the sources, the degree of maturation, and the influence from autochthonous biological activity of DOM, as listed in the following:

$$
\begin{aligned}
\mathrm{FI} & =\frac{f_{450}}{f_{500}}, \\
\mathrm{HIX} & =\frac{H}{L}, \\
\mathrm{BIX} & =\frac{f_{380}}{f_{430}},
\end{aligned}
$$

where $f_{450}$ and $f_{500}$ are the intensities at the emission wavelength of $450 \mathrm{~nm}$ and $500 \mathrm{~nm}$ at the excitation wavelength $370 \mathrm{~nm}$, respectively $[41,42]$, while $f_{380}$ and $f_{430}$ are the fluorescence intensity at the emission wavelength of $380 \mathrm{~nm}$ and $430 \mathrm{~nm}$ at the excitation wavelength $310 \mathrm{~nm}$, respectively [27, 38]. $H$ and $L$ represent the integral values from 435 to $480 \mathrm{~nm}$ and 300 to $345 \mathrm{~nm}$ at the excitation wavelength $254 \mathrm{~nm}$, respectively [27, 43].

As listed in Table 5, the mean FI values of the five sites' soil samples were $1.54,1.61,1.46,1.52$, and 1.51 for Y-1, Y-4, Y-10, Y-15, and Y-20, respectively. Considering that the terrestrial and microbial end-member values were reported as 1.4 and 1.9 [41, 42], the FI values in this study suggested that the sources of DOM in the soil samples were possibly assigned
TABLE 5: Results of UV-Visible spectroscopy and EEM fluorescence spectroscopy.

\begin{tabular}{lccccc}
\hline Sample point & SUVA $_{254}\left(\mathrm{mg}^{-1} \cdot \mathrm{m}^{-1}\right)$ & SR & FI & BIX & HIX \\
\hline Y-1 & 5.39 & 0.64 & 1.54 & 0.56 & 14.7 \\
Y-4 & 5.90 & 1.07 & 1.61 & 0.48 & 18.90 \\
Y-10 & 4.83 & 0.92 & 1.46 & 0.57 & 2.17 \\
Y-15 & 5.33 & 0.95 & 1.52 & 0.43 & 6.16 \\
Y-20 & 4.39 & 0.77 & 1.51 & 0.67 & 3.66 \\
\hline
\end{tabular}

to both terrestrial and microbial sources, which cannot be influenced by the afforestation time. The mean HIX values in this study were $14.70,18.90,2.17,6.16$, and 3.66 for Y-1, Y-4, Y-10, Y-15, and Y-20, respectively. It was believed that the high HIX values at the region of 10-16 are the indicator of the strongly humic organic substances (terrestrial origin), whereas low values $(<4)$ imply the presence of autochthonous organic components [38-40].

Compared to the samples of the Y-10 and Y-20 sites, which mainly consisted of autochthonous organic matters (HIX values < 4.05), the DOM extracted from the soil samples of the other three sites (Y-1, Y-4, and Y-15) was composed of both allochthonous and autochthonous organic substances. Previous study reported that the allochthonous organic matters originated from incomplete decomposition of plant and animal residues, while the autochthonous organic ones may derive from the photosynthesis [40]. High BIX values $(>1)$ correspond to autochthonous sources, while low BIX values $(<1)$ imply low abundance of organic matter of biological origin [38-40]. The mean BIX values of the five sites' soil samples were $0.56,0.48,0.57,0.43$, and 0.67 for Y-1, Y-4, Y-10, Y-15, and Y-20, respectively, indicative of low abundance of biological origin organic components.

3.2.3. ${ }^{1} \mathrm{H}$ NMR Spectroscopy. Proton NMR spectroscopy $\left({ }^{1} \mathrm{H}\right.$ NMR) was often utilized to characterize the composition of the DOM in soil samples, which can provide semiquantitative 


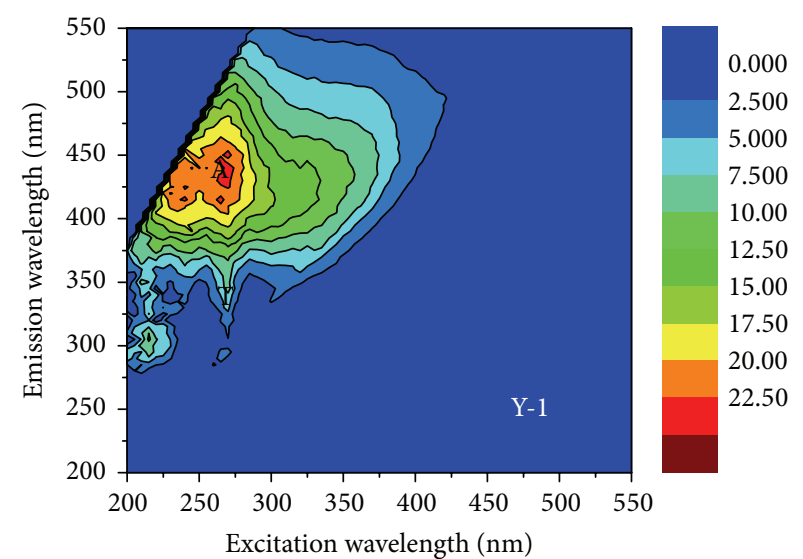

(a)

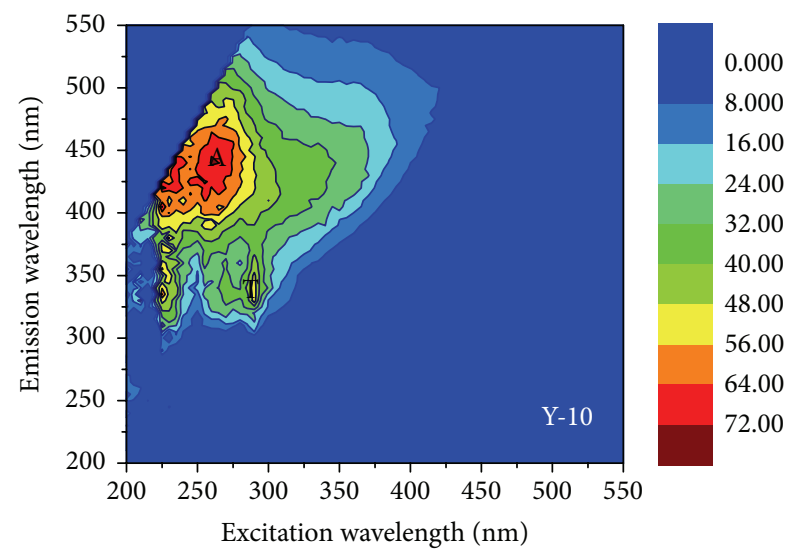

(c)

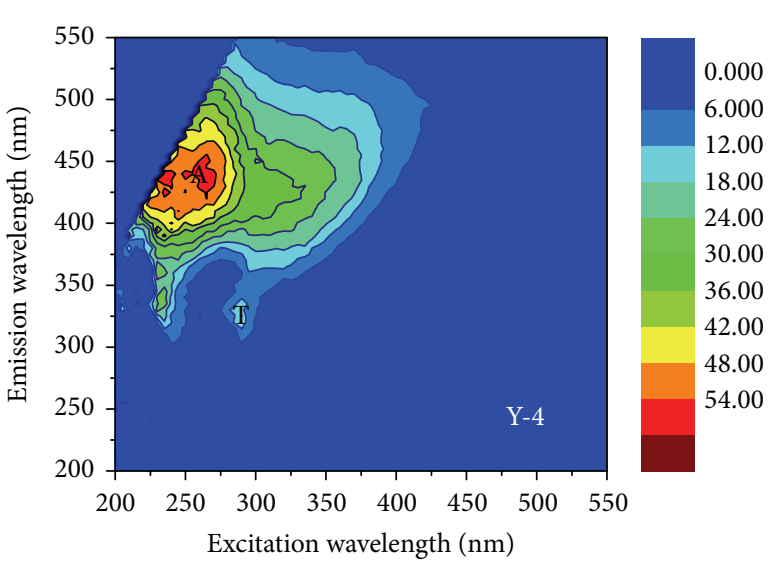

(b)

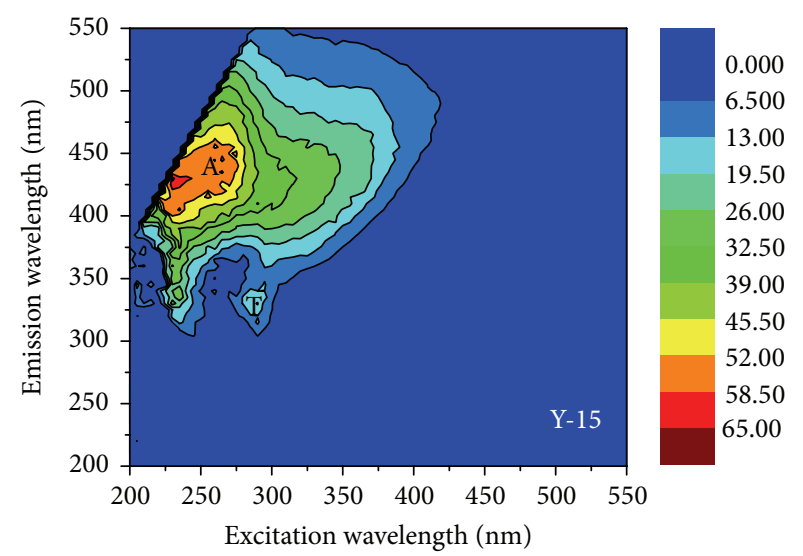

(d)

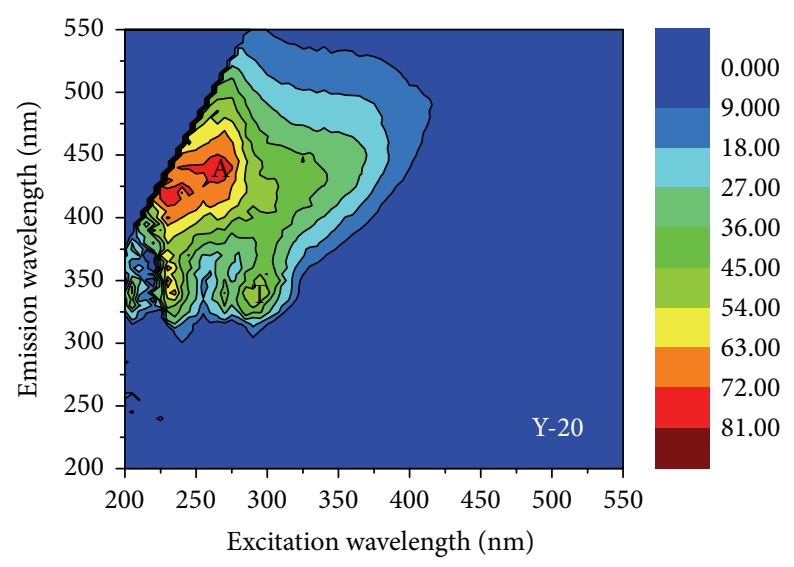

(e)

FIGURE 3: EEM fluorescence contour profiles of the five sites' DOM.

information on aromatic, aliphatic, and carboxylic groups [27, 44, 45]. Much different from UV-Visible spectroscopy and EEM, ${ }^{1} \mathrm{H}$ NMR can give us the content and structural information via the corresponding integrated areas and the chemical shifts $\left(\delta_{\mathrm{H}}\right)[18,19]$. As illustrated in Figure 4 , the ${ }^{1} \mathrm{H}$ NMR results of the five sites exhibit some distinct peaks overlaying bands, implying the existence of complicated mixtures in the DOM. Despite the large variety of overlapping resonances, each ${ }^{1} \mathrm{H}$ NMR spectrum was analyzed based on the chemical shift assignments following the method described in the previously reported literatures for soil DOM [27]. The integrated regions in the ${ }^{1} \mathrm{H}$ NMR spectra were listed as follows: $\delta_{\mathrm{H}}=0.5-2.9 \mathrm{ppm}$ (aliphatic protons, $\mathrm{H}-\mathrm{C}$ ); $\delta_{\mathrm{H}}=3.0-4.2 \mathrm{ppm}$ (carbohydrates, $\mathrm{H}-\mathrm{C}-\mathrm{C}=$ ); and $\delta_{\mathrm{H}}=6.0-8.0 \mathrm{ppm}$ (aromatic protons) [27]. The spectra of five sites were depicted in Figure 5. The ${ }^{1} \mathrm{H}$ NMR results of 

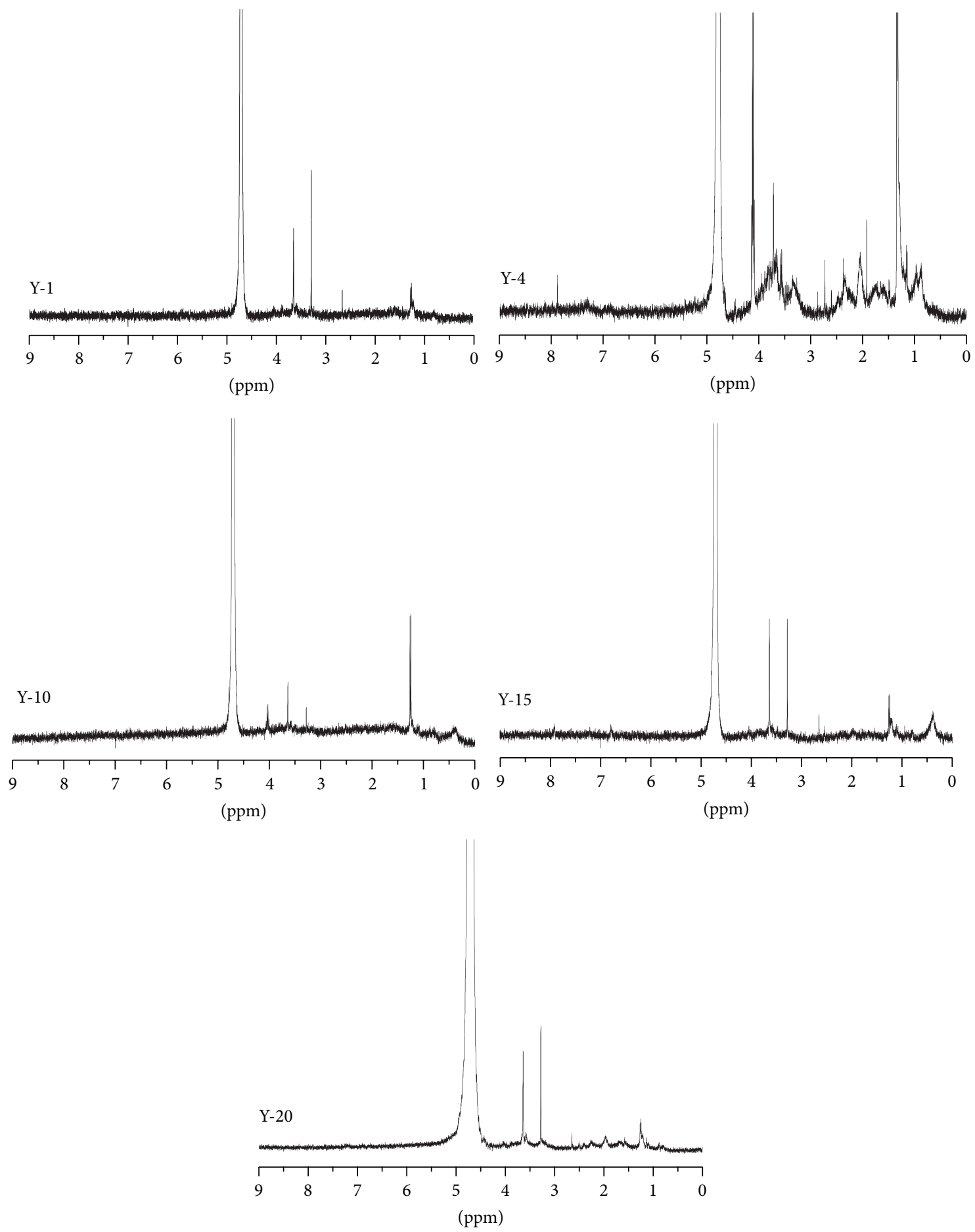

FIGURE $4:{ }^{1} \mathrm{H}$ NMR spectra of DOM in the extracted samples of the five sampling sites.

the five sites exhibited similar patterns as to functional group composition, suggesting the presence of more aliphatic and carbohydrates structures and less quantity of aromatic organic matters (Table 6).

The content of saturated aliphatic substances in site Y-1 (4.2\%) was lower than other sites $(68.1 \%, 64.5 \%, 36.7 \%$, and $34.0 \%$ for Y-4, Y-10, Y-15, and Y-20, resp.), while the content of carbohydrates (92.2\%) was higher than other sites (33.5\%, $33.5 \%, 59.8 \%$, and $64.2 \%$, for Y-4, Y-10, Y-15, and Y-20, resp.). The content of aromatic structures in the five sites was 3.6\%, $4.7 \%, 2 \%, 3.5 \%$, and $1.8 \%$ for Y-1, Y- $4, \mathrm{Y}-10, \mathrm{Y}-15$, and Y-20, respectively. The results implied that the saturated aliphatic chains and carbohydrates were the main structures in afforestation forest land. 
TABLE 6: Results of the ${ }^{1} \mathrm{H}$ NMR analyses.

\begin{tabular}{lccc}
\hline $\begin{array}{l}\text { Sample } \\
\text { sites }\end{array}$ & $\begin{array}{c}\text { \% aliphatics } \\
(0.5-3.00 \mathrm{ppm})\end{array}$ & $\begin{array}{c}\text { \% carbohydrates } \\
(3.00-4.2 \mathrm{ppm})\end{array}$ & $\begin{array}{c}\text { \% aromatics } \\
(6.00-8.00 \mathrm{ppm})\end{array}$ \\
\hline Y-1 & 4.2 & 92.2 & 3.6 \\
Y-4 & 61.8 & 33.5 & 4.7 \\
Y-10 & 64.5 & 33.5 & 2 \\
Y-15 & 36.7 & 59.8 & 3.5 \\
Y-20 & 34 & 64.2 & 1.8 \\
\hline
\end{tabular}

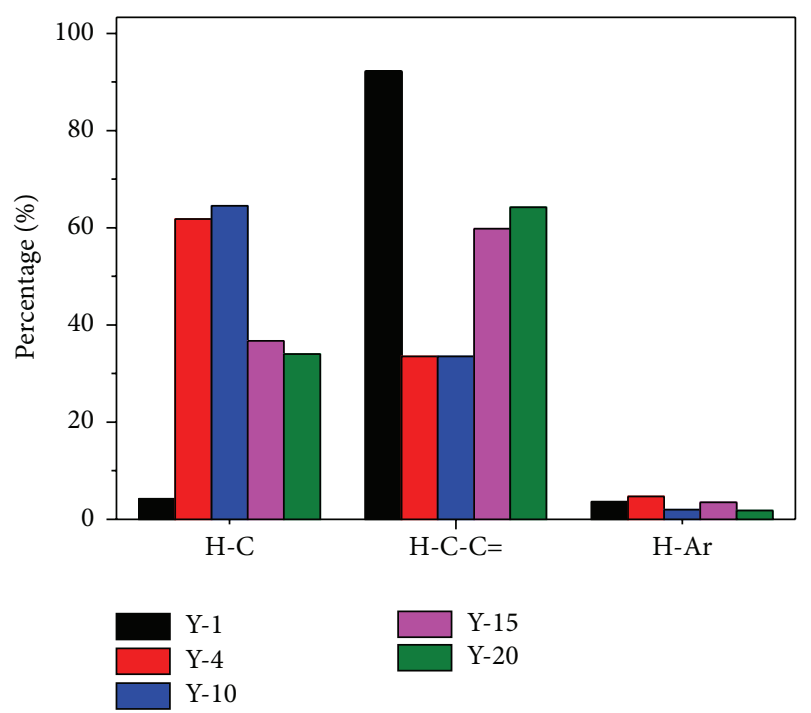

FIGURE 5: The relative abundance of each type of protons, estimated as the partial integrals of the spectra reported in Figure 4.

\section{Conclusions}

With this study, a preliminary soil quality evaluation were carried out based on soil texture and some chemical indicators like TOC, TN, TP, K ${ }^{+}, \mathrm{MBC}$, and DOC. Particularly, the DOM in the soil samples with different afforestation time was further characterized via DOC, UV-Visible spectroscopy, EEM fluorescence spectroscopy, and ${ }^{1} \mathrm{H}$ NMR spectroscopy. The results of EEM fluorescence spectroscopy demonstrated that UV humic-like substances were the major fluorophores components in the DOM of the soil samples. The DOM in the soil samples was mainly composed of aliphatic chains and aromatic components with carbonyl, carboxyl, and hydroxyl groups. DOM in soils plays a crucial role in soil physical, chemical, and biological processes, but little information is available on the formation and biodegradability of plantderived DOM in afforestation forest soil. With the development of afforestation forest in Beijing, it is necessary to further investigate the DOM distribution and the corresponding influence on soil quality, plants growth, and ecosystem.

\section{Competing Interests}

The authors declare that there are no competing interests regarding the publication of this paper.

\section{Acknowledgments}

This study was supported by the Fund of 12th FiveYear National Science and Technology Support Program (2013BAJ02B0404).

\section{References}

[1] S. Cao, "Why large-scale afforestation efforts in China have failed to solve the desertification problem," Environmental Science and Technology, vol. 42, no. 6, pp. 1826-1831, 2008.

[2] Y. Qiao, J. Wang, and J. Li, “The summary and reflection of Beijing's plain reforestation: taking Qingyundian of Daxing district as an example," Forestry Economics, vol. 4, article 005, 2014.

[3] K. Kaiser, G. Guggenberger, and W. Zech, "Sorption of DOM and DOM fractions to forest soils," Geoderma, vol. 74, no. 3-4, pp. 281-303, 1996.

[4] R. G. Qualls and B. L. Haines, "Biodegradability of dissolved organic matter in forest throughfall, soil solution, and stream water," Soil Science Society of America Journal, vol. 56, no. 2, pp. 578-586, 1992.

[5] R. Bi, Q. Lu, T. Yuan, S. Zhou, Y. Yuan, and Y. Cai, "Electrochemical and spectroscopic characteristics of dissolved organic matter in a forest soil profile," Journal of Environmental Sciences, vol. 25, no. 10, pp. 2093-2101, 2013.

[6] X.-J. Guo, N.-M. Zhu, L. Chen, D.-H. Yuan, and L.-S. He, "Characterizing the fluorescent properties and copper complexation of dissolved organic matter in saline-alkali soils using fluorescence excitation-emission matrix and parallel factor analysis," Journal of Soils and Sediments, vol. 15, no. 7, pp. 14731482, 2015.

[7] B. Marschner and K. Kalbitz, "Controls of bioavailability and biodegradability of dissolved organic matter in soils," Geoderma, vol. 113, no. 3-4, pp. 211-235, 2003.

[8] K. Kalbitz, S. Solinger, J.-H. Park, B. Michalzik, and E. Matzner, "Controls on the dynamics dissolved organic matter in soils: a review," Soil Science, vol. 165, no. 4, pp. 277-304, 2000.

[9] D. L. Jones, P. Simfukwe, P. W. Hill, R. T. E. Mills, and B. A. Emmett, "Evaluation of dissolved organic carbon as a soil quality indicator in national monitoring schemes," PLoS ONE, vol. 9, no. 3, Article ID e90882, 2014.

[10] T. Yuan, Y. Yuan, S. Zhou, F. Li, Z. Liu, and L. Zhuang, "A rapid and simple electrochemical method for evaluating the electron transfer capacities of dissolved organic matter," Journal of Soils and Sediments, vol. 11, no. 3, pp. 467-473, 2011.

[11] T. Ohno, I. J. Fernandez, S. Hiradate, and J. F. Sherman, "Effects of soil acidification and forest type on water soluble soil organic matter properties," Geoderma, vol. 140, no. 1-2, pp. 176-187, 2007.

[12] G. F. Vance and M. B. David, "Chemical characteristics and acidity of soluble organic substances from a northern hardwood forest floor, central Maine, USA," Geochimica et Cosmochimica Acta, vol. 55, no. 12, pp. 3611-3625, 1991.

[13] Q.-Y. Wang, Y. Wang, Q.-C. Wang et al., "Effects of land use changes on the spectroscopic characterization of hot-water extractable organic matter along a chronosequence: correlations with soil enzyme activity," European Journal of Soil Biology, vol. 58, pp. 8-12, 2013.

[14] M. A. Rab, "Soil physical and hydrological properties following logging and slash burning in the Eucalyptus regnans forest of southeastern Australia," Forest Ecology and Management, vol. 84, no. 1-3, pp. 159-176, 1996. 
[15] M. Han, G. Ji, and J. Ni, "Washing of field weathered crude oil contaminated soil with an environmentally compatible surfactant, alkyl polyglucoside," Chemosphere, vol. 76, no. 5, pp. 579586, 2009.

[16] X. Bi, L. Ren, M. Gong, Y. He, L. Wang, and Z. Ma, “Transfer of cadmium and lead from soil to mangoes in an uncontaminated area, Hainan Island, China," Geoderma, vol. 155, no. 1-2, pp. 115120,2010

[17] J. Akagi, Á. Zsolnay, and F. Bastida, "Quantity and spectroscopic properties of soil dissolved organic matter (DOM) as a function of soil sample treatments: air-drying and pre-incubation," Chemosphere, vol. 69, no. 7, pp. 1040-1046, 2007.

[18] N. Roig, J. Sierra, E. Martí, M. Nadal, M. Schuhmacher, and J. L. Domingo, "Long-term amendment of Spanish soils with sewage sludge: effects on soil functioning," Agriculture, Ecosystems and Environment, vol. 158, pp. 41-48, 2012.

[19] J. L. Weishaar, G. R. Aiken, B. A. Bergamaschi, M. S. Fram, R. Fujii, and K. Mopper, "Evaluation of specific ultraviolet absorbance as an indicator of the chemical composition and reactivity of dissolved organic carbon," Environmental Science and Technology, vol. 37, no. 20, pp. 4702-4708, 2003.

[20] S. A. Green and N. V. Blough, "Optical absorption and fluorescence properties of chromophoric dissolved organic matter in natural waters," Limnology and Oceanography, vol. 39, no. 8, pp. 1903-1916, 1994.

[21] P. J. Seaton, R. J. Kieber, J. D. Willey, G. B. Avery, and J. L. Dixon, "Seasonal and temporal characterization of dissolved organic matter in rainwater by proton nuclear magnetic resonance spectroscopy," Atmospheric Environment, vol. 65, pp. 52-60, 2013.

[22] J. Amador, P. J. Milne, C. A. Moore, and R. G. Zika, "Extraction of chromophoric humic substances from seawater," Marine Chemistry, vol. 29, pp. 1-17, 1990.

[23] C. A. Stedmon and R. Bro, "Characterizing dissolved organic matter fluorescence with parallel factor analysis: a tutorial," Limnology and Oceanography: Methods, vol. 6, no. 11, pp. 572579, 2008.

[24] P. S. M. Santos, M. Otero, R. M. B. O. Duarte, and A. C. Duarte, "Spectroscopic characterization of dissolved organic matter isolated from rainwater," Chemosphere, vol. 74, no. 8, pp. 1053-1061, 2009.

[25] C. Zhao, C.-C. Wang, J.-Q. Li, C.-Y. Wang, P. Wang, and Z.-J. Pei, "Dissolved organic matter in urban stormwater runoff at three typical regions in Beijing: chemical composition, structural characterization and source identification," RSC Advances, vol. 5, no. 90, pp. 73490-73500, 2015.

[26] Z. Wang and Q. Wang, "The spatial heterogeneity of soil physical properties in forests," Acta Ecologica Sinica, vol. 20, no. 6, pp. 945-950, 1999.

[27] M. L. Fernández-Romero, J. M. Clark, C. D. Collins, L. ParrasAlcántara, and B. Lozano-García, "Evaluation of optical techniques for characterising soil organic matter quality in agricultural soils," Soil and Tillage Research, vol. 155, pp. 450-460, 2016.

[28] K. Kalbitz, J. Schmerwitz, D. Schwesig, and E. Matzner, "Biodegradation of soil-derived dissolved organic matter as related to its properties," Geoderma, vol. 113, no. 3-4, pp. 273291, 2003.

[29] R. M. B. O. Duarte and A. C. Duarte, "Application of nonionic solid sorbents (XAD Resins) for the isolation and fractionation of water-soluble organic compounds from atmospheric aerosols," Journal of Atmospheric Chemistry, vol. 51, no. 1, pp. 79-93, 2005.
[30] N. Senesi, T. M. Miano, M. R. Provenzano, and G. Brunetti, "Spectroscopic and compositional comparative characterization of I.H.S.S. reference and standard fulvic and humic acids of various origin," Science of the Total Environment, vol. 81-82, pp. 143-156, 1989.

[31] X.-S. He, B.-D. Xi, Y.-H. Jiang et al., "Structural transformation study of water-extractable organic matter during the industrial composting of cattle manure," Microchemical Journal, vol. 106, pp. 160-166, 2013.

[32] T. Jamieson, E. Sager, and C. Guéguen, "Characterization of biochar-derived dissolved organic matter using UV-visible absorption and excitation-emission fluorescence spectroscopies," Chemosphere, vol. 103, pp. 197-204, 2014.

[33] J. R. Helms, A. Stubbins, J. D. Ritchie, E. C. Minor, D. J. Kieber, and K. Mopper, "Absorption spectral slopes and slope ratios as indicators of molecular weight, source, and photobleaching of chromophoric dissolved organic matter," Limnology and Oceanography, vol. 53, no. 3, pp. 955-969, 2008.

[34] C. A. Stedmon, S. Markager, and H. Kaas, "Optical properties and signatures of chromophoric dissolved organic matter (CDOM) in Danish coastal waters," Estuarine, Coastal and Shelf Science, vol. 51, no. 2, pp. 267-278, 2000.

[35] J. B. Fellman, D. V. D'Amore, E. Hood, and R. D. Boone, "Fluorescence characteristics and biodegradability of dissolved organic matter in forest and wetland soils from coastal temperate watersheds in southeast Alaska," Biogeochemistry, vol. 88, no. 2, pp. 169-184, 2008.

[36] J. Sanderman, J. A. Baldock, and R. Amundson, "Dissolved organic carbon chemistry and dynamics in contrasting forest and grassland soils," Biogeochemistry, vol. 89, no. 2, pp. 181-198, 2008.

[37] K. Fujii, M. Uemura, C. Hayakawa et al., "Fluxes of dissolved organic carbon in two tropical forest ecosystems of East Kalimantan, Indonesia," Geoderma, vol. 152, no. 1-2, pp. 127-136, 2009.

[38] A. Huguet, L. Vacher, S. Relexans, S. Saubusse, J. M. Froidefond, and E. Parlanti, "Properties of fluorescent dissolved organic matter in the Gironde Estuary," Organic Geochemistry, vol. 40, no. 6, pp. 706-719, 2009.

[39] A. Huguet, L. Vacher, S. Saubusse et al., "New insights into the size distribution of fluorescent dissolved organic matter in estuarine waters," Organic Geochemistry, vol. 41, no. 6, pp. 595610,2010

[40] P. R. Salve, H. Lohkare, T. Gobre et al., "Characterization of chromophoric dissolved organic matter (CDOM) in rainwater using fluorescence spectrophotometry," Bulletin of Environmental Contamination and Toxicology, vol. 88, no. 2, pp. 215-218, 2012.

[41] D. M. McKnight, E. W. Boyer, P. K. Westerhoff, P. T. Doran, T. Kulbe, and D. T. Andersen, "Spectrofluorometric characterization of dissolved organic matter for indication of precursor organic material and aromaticity," Limnology and Oceanography, vol. 46, no. 1, pp. 38-48, 2001.

[42] R. Jaffé, J. N. Boyer, X. Lu et al., "Source characterization of dissolved organic matter in a subtropical mangrove-dominated estuary by fluorescence analysis," Marine Chemistry, vol. 84, no. 3-4, pp. 195-210, 2004.

[43] T. Ohno, "Fluorescence inner-filtering correction for determining the humification index of dissolved organic matter," Environmental Science \& Technology, vol. 36, no. 4, pp. 742-746, 2002. 
[44] L. A. Cardoza, A. K. Korir, W. H. Otto, C. J. Wurrey, and C. K. Larive, "Applications of NMR spectroscopy in environmental science," Progress in Nuclear Magnetic Resonance Spectroscopy, vol. 45, no. 3-4, pp. 209-238, 2004.

[45] C. M. Preston, "Applications of NMR to soil organic matter analysis: history and prospects," Soil Science, vol. 161, no. 3, pp. 144-166, 1996. 

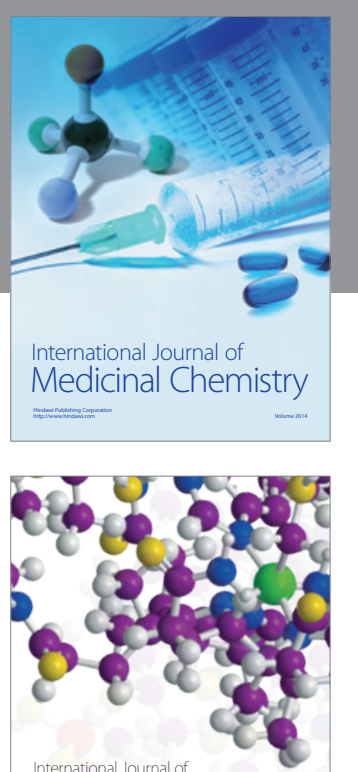

Carbohydrate Chemistry

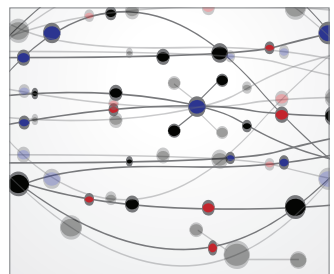

The Scientific World Journal
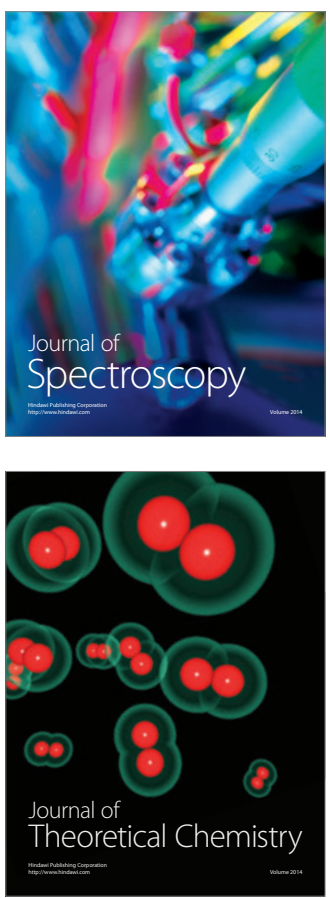
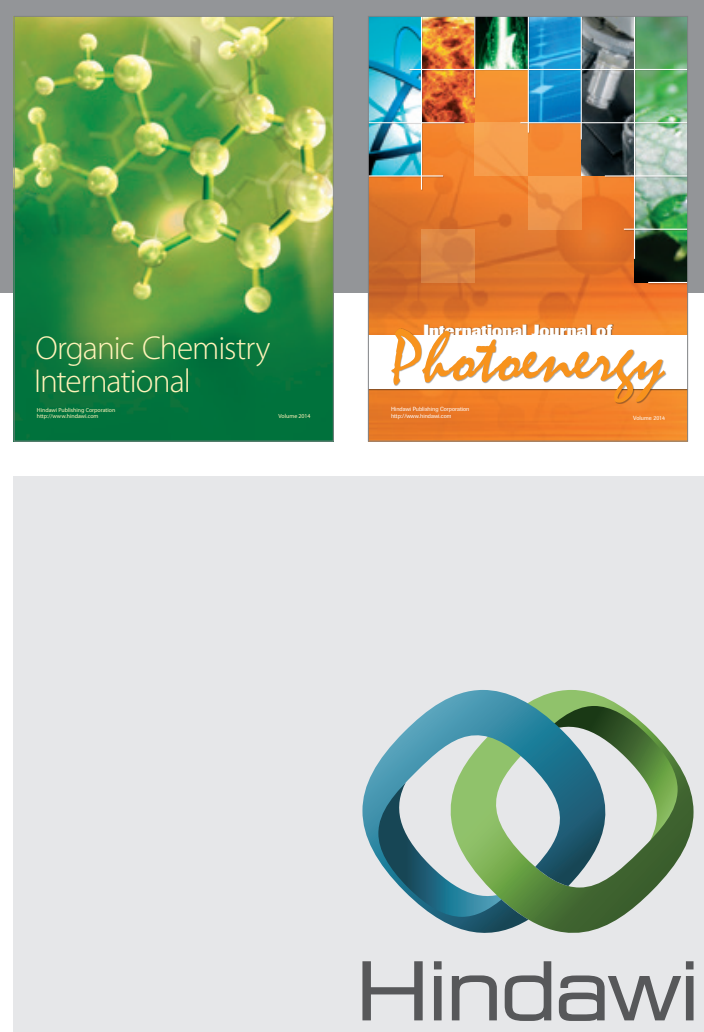

Submit your manuscripts at

http://www.hindawi.com

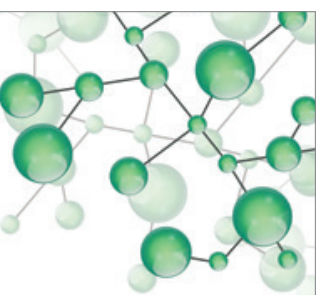

International Journal of

Inorganic Chemistry

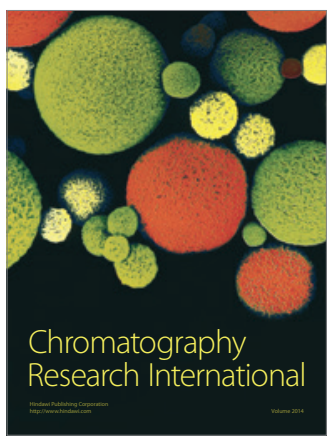

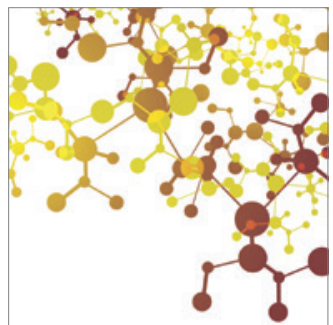

Applied Chemistry
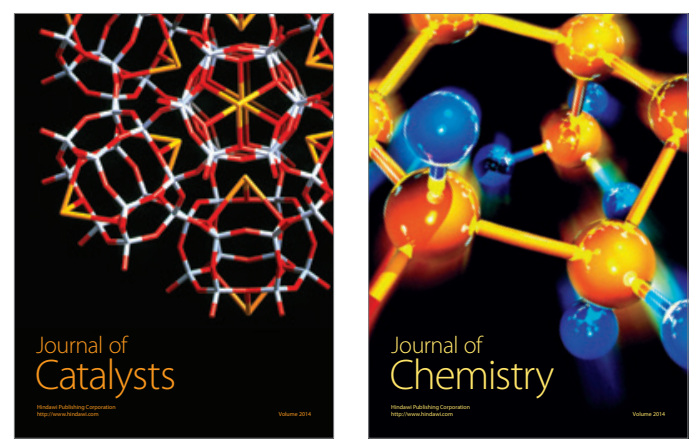
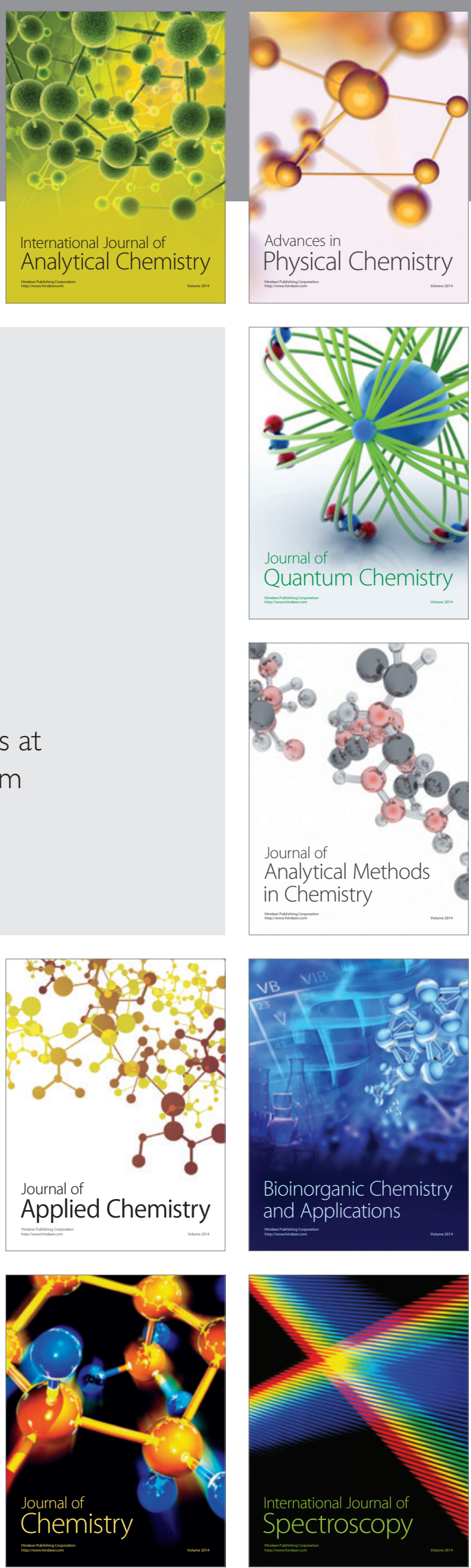